\title{
Study on the Importance of Superb Vocal Techniques in Interpreting Vocal Works
}

\author{
Songzhang Liu \\ Heyuan Polytechnic, Guangdong, 517000, China
}

Keywords: Vocal art; vocal skills; importance

Abstract: Vocal music skills are essential to the expression and completion of vocal music. The use of vocal music techniques can deepen the connotation of vocal music and express the emotions in vocal works. The vocal skills can be realized through the expression of language and the use of sound. It can be seen that the perfect harmony between vocal skills and language and sound, but it is precisely because of this that the vocal skills are established in vocal art. The importance of becoming an indispensable part of vocal art expression. This paper explains the importance of vocal skills in the vocal skills of vocal music from the analysis of the connotation of vocal music, the sublimation of vocal art, the expression of vocal art style and the development of vocal art.

Vocal music art is an art form expressed by the artist through the analysis of life. Through the form of art, it expresses the profound life philosophy of the work, expresses the emotions of the artist, and uses various vocal techniques to realize the vocal art. Expression in emotion, connotation, style, etc. Vocal music is the soul of vocal art. It is the essence of a good vocal work. The use of vocal techniques is good and bad and directly affects the expressiveness and appeal of the entire vocal art. Without the support of vocal techniques, the expression of vocal art seems so hollow, without a trace of vitality, let alone the emotional connotation of vocal music. In the continuous development of vocal art, vocal techniques have also undergone great changes. More and more vocal skills are used to make the kind of emotions and environmental appeals that art works want to show. Become more vivid. Only by using appropriate vocal skills can better express the appeal of vocal art works, further promote the development of art works, and provide a broader platform for vocal skills to achieve mutual promotion and common development[1].

\section{Vocal music skills sublimate the connotation of vocal art}

The profound connotation meaning embodied in vocal art often has a high abstract meaning, which is basically expressed in a very concealed way. This very abstract expression cannot be expressed through the description of words, the communication of language, or even the use of musical instruments. At this time, the vocal skills such as the singing skills and the level of sounds of the performers can only be profound in the art of vocal music. Connotation is expressed. The vocal skill is simply the combination of the performer's voice and language, the singer's various performance techniques, the low and high voice, the speed of speech, etc., the joy, sadness, despair, and vocal art. The meaning of diversification and other connotations are expressed. An excellent 
example of the connotation of the role of art is the National Anthem of the People's Republic of China, "The March of the Volunteers". The March of the Volunteers is a good example of the eternal spirit of the Chinese people in the struggle against external vocal skills. The complete expression of the unyielding in the predicament appears. There is also the "Night in the Outskirts of Moscow". This song is a kind of harmonious natural beauty through the soft voice of the artist. It emphasizes the beauty of love for young people and the cherishment of love[2].

\section{Vocal skills strengthen the emotional expression in vocal art}

The use of vocal techniques and the expression of emotions are the basic elements of vocal art and the basis for the expression of artistic works. In the actual performance process, the two are combined and interact. The expression of emotions in vocal techniques is a deepening and strengthening effect, and emotions are the premise of using vocal techniques. The vocal skills used in different emotions will be different. Through the study of a large number of works of art in the past, it can be found that a work of art that does not have a good combination of vocal skills and emotions often gives a work of art that deviates from the expression of the work, giving people a feeling of opposition. It makes the whole works of art unable to express the spirit that the writer wants to reflect. There is a complementary promotion between vocal skills and emotions. Without the support of artistic skills, there will be a lot of vacancies in the way of expression, which will seriously affect the performance of vocal art and appear to be emotionally weak and powerful. The body without the skeleton support breaks at the touch. The same vocal skills without emotion, what the viewers bring is only the expression of monotonous artistic skills. Without the influence of a little bit, the spirit of vocal art cannot be conveyed to the viewer. The most famous of the singing styles of "Farewell Time" is the single of the British music drama's first daughter Sarah Brightman and the Italian blind singer Andrei Bocelli. Throughout the performance, the two singers performed very well on the music in the whole song, the emotional grasp, the degree of vocal skill control, and the control of the intensity. With a very obvious manifestation, it is a very good performance of the emotions of the works through the skills of vocal music[3]. The weight of the influence factors of vocal skills is shown in the following table.

Table 1 Weight of the influence factors of vocal skills

\begin{tabular}{|c|c|c|c|}
\hline Index & Techniques & Emotion & Performance \\
\hline Weight & 0.4155 & 0.2674 & 0.3171 \\
\hline
\end{tabular}

\section{Vocal skills better highlight the style of vocal art}

Emotion is an indispensable part of vocal art, and the style of art is the core pillar of vocal art. The style of vocal art can better reflect the emotions in vocal art, and at the same time, it will render the environmental tone of vocal art, reflecting the emotional atmosphere contained in vocal music art. The vocal skills of the artistic style are manifested by the way the expresser speaks, the speed of the singing, the low and high level of the sound, the speed of breathing, the direct feeling of the person, and the creation of the environment[4]. The performance of vocal skills will present different artistic styles, which will result in a diversified expression of vocal art, and also create different regional styles in different regions. For the northerners, due to the living environment and the special circumstances of geography, the people of the North are relatively magnified, free to speak, and express their emotions directly. This also gives birth to a northern language style with a high level of speech and a strong tone change. The realization of the work is relatively straightforward. For the southerners, the colorfulness of life and the introversion of people's 
character have created the characteristics of the southern people's way of speaking, gentle speech, and more emphasis on the processing of tones. The southern little family sentiment. For example, Hubei's famous "Honghu Water Waves and Waves" is a kind of relaxed and harmonious southern small family flavor. Shaanxi's "Xintianyou" is very high-spirited in performance, reflecting the unconstrainedness of the northern people. No, free, unrestrained feelings. The development trend of the number of vocal skills is as follows.

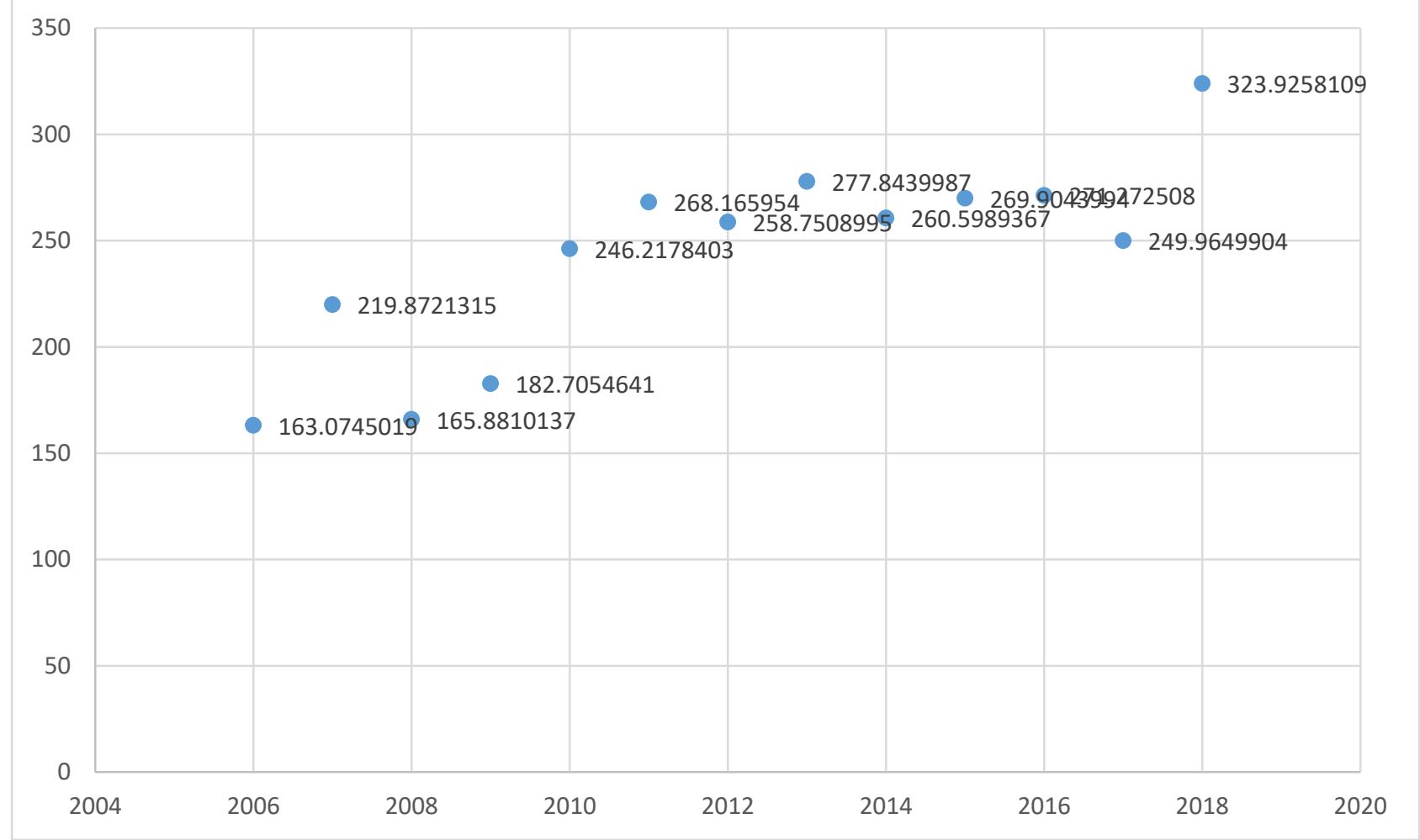

Figure 1 Development trend of the number of vocal skills

Compared with other genres, artistic songs have more elaborate artistic ideas. Their accompaniment is fresh and beautiful. Most of them are songs of excellent lyrical short poems. It can be seen that art songs are usually in solo form and concerts accompanied by piano. The form of performance, such as "Three Wishes of Roses", "I live in the Yangtze River", "Spring Song", etc.; the genre of mass songs reflects the ideal aspirations of the people, reflecting the people's concern for social life, and the tunes are magnificent and heroic. Most of them are easy to catch up. Therefore, the masses of songs take the form of collective singing such as singing and chorus, such as "Graduation Song" and "Guerrilla Song". Similarly, the praise song is also a hymn of Christian church in the form of chorus. The large-scale vocal genre in vocal art is a comprehensive art that integrates music, drama, dance and art. It is because of its comprehensiveness that it also includes solo, chorus and chorus in the practice of singing. And sing in various forms, such as ("White Hair Girl", "Cangyuan", etc.; of course, there are also vocal genres with more flexible singing styles, such as Chinese lyrics Its historical development process determines its absorption of songs and dances, folk songs, minor notes, etc., which contain many folks. It has folk characteristics, so the singing forms are also diverse, lively and interesting, with self-singing and side-swinging. Sing, sing by one or more people, etc.

\section{Vocal skills promote the development of vocal art}

In the continuous development of human spiritual civilization, vocal music is an expression of 
people's emotions and an important way of people's spiritual sustenance. Vocal art not only conveyed some important information of that era, but also conveyed a spiritual power of the society at that time. The development of vocal art is a perfect improvement of people's aesthetic death, and it also plays an important role in promoting human spirit. The continuous improvement of human society, people's requirements for vocal music are also improved, and the improvement of vocal skills is an important way to improve the connotation of vocal art, an important means to make up for the deficiencies in current vocal art, and the best choice for vocal music. . The embodiment of the spirit of vocal music, the expression of emotion, and the expression of thought can all be expressed through vocal techniques. Good vocal art cannot be separated from superb vocal skills. The continuous improvement of vocal skills has promoted the development of vocal art, and the advancement of vocal art has also produced more vocal skills[5].

\section{Conclusions}

Through the analysis and analysis of the vocal skills in deepening the connotation of vocal art, expressing the emotions of artistic works, highlighting the vocal artistic style and the development of vocal art, the analysis of a large number of works of art shows that vocal skills are the expression of vocal art. An indispensable part of the game has an important role in promoting the development of vocal music. The use of exquisite vocal techniques can well reflect the style of works in vocal art and enhance the epochal meaning of vocal art. The continuous improvement of vocal skills, the exploration of good vocal techniques.

\section{References}

[1] Iris Meerschman,Kim Bettens,Stefanie Dejagere,Lieselot Tetaert,Evelien D'haeseleer,Sofie Claeys,Kristiane Van Lierde. Effect of Two Isolated Vocal-facilitating Techniques Chant Talk and Pitch Inflections on the Phonation of Female Speech-language Pathology Students: A Pilot Study [J]. Journal of Voice, 2016,30(6).

[2] Fatma Esen Aydınlı,Esra Özcebe,Maviş E. Kulak Kayıkçı,Taner Yılmaz,Fatma F. Özgür. Investigating the Effects of Glottal Stop Productions on Voice in Children With Cleft Palate Using Multidimensional Voice Assessment Methods [J]. Journal of Voice, 2016,30(6).

[3] Linqing Li,Jeanna M. Stiadle,Hang K. Lau,Aidan B. Zerdoum,Xinqiao Jia,Susan L. Thibeault,Kristi L. Kiick. Tissue engineering-based therapeutic strategies for vocal fold repair and regeneration [J]. Biomaterials, 2016,108.

[4] Shellie A. Beeman. Perceptions of Voice Teachers Regarding Students' Vocal Behaviors During Singing and Speaking [J]. Journal of Voice, 2017,31(1).

[5] Rebecca R. Vos,Helena Daffern,David M. Howard. Resonance Tuning in Three Girl Choristers [J]. Journal of Voice, 2017,31(1). 